\title{
PENGUKURAN INDEKS KEPUASAN MASYARAKAT (IKM) PELAYANAN KESEHATAN DI PUSKESMAS KABUPATEN HULU SUNGAI UTARA
}

\author{
Measurement of Community Satisfaction Index (CSI) Health Services in Health \\ District Hulu Sungai Utara
}

\author{
Dedie Fahamsyah ${ }^{1}, \mathrm{C}$ Isnur Hatta ${ }^{2}$, Mahyuliansyah ${ }^{3}$ \\ 1,3 Dinas Kesehatan Hulu Sungai Utara, Indonesia \\ 2 Fakultas Kesehatan Masyarakat, Universitas Airlangga, Indonesia \\ E-mail: dfahamsyah@gmail.com
}

\begin{abstract}
Background: To know people's judgment of the services provided by Hulu Sungai Utara public health center (puskesmas) to the public, there should be a measure of the level of people's satisfaction with health services. Aim: The purpose of this study was to measure the peoples's satisfaction based on Permenpan RB number 16 in 2014 and measure peoples's satisfaction based on the Customer Satisfaction Index (CSIndex).

Method: This study was observational. There were 13 health centers in Hulu Sungai Utara analyzed. The sample was 450 people who used health services in Hulu Sungai Utara public health centers.

Results: The first analysis used the data by Permenpan RB No. 16 of 2014, and the second used the Customer Satisfaction Index (CSIndex). The results of this research based Permenpan number 16 of 2014 found all public health centers in Hulu Sungai Utara had a value of community satisfaction index in either category. By using CSIndex, it was found that the entire public health centers had a high satisfaction.

Conclusions: It can be concluded that the value of Community Satisfaction Index in all public health centres was rather satisfied. Some reconstruction for supporting facilities, such as clean toilet, comfortable and clean waiting room, service information, service flow, management improvement, and product marketing should be done.
\end{abstract}

Keywords: CSIndeks, Community Satisfaction Index, Permenpan, Health Center

\section{ABSTRAK}

Latar Belakang: Untuk mengetahui penilaian masyarakat terhadap pelayanan yang diberikan oleh Puskesmas Kabupaten Hulu Sungai Utara kepada masyarakat, maka perlu dilakukan suatu pengukuran berupa tingkat kepuasan masyarakat terhadap pelayanan kesehatan yang diterima.

Tujuan: Tujuan dari penelitian ini adalah mengukur kepuasan masyarakat berdasarkan pada Permenpan RB nomor 16 tahun 2014 dan mengukur kepuasan masyarakat berdasarkan pada Customer Satisfaction Indeks (CSIndeks).

Metode: Penelitian ini bersifat observasional. Unit analisis penelitian ini adalah 13 puskesmas di Kabupaten Hulu Sungai Utara, sampel penelitian adalah masyarakat yang memanfaatkan pelayanan kesehatan di Puskesmas Kabupaten Hulu Sungai Utara dan jumlah sampel ditetapkan sebanyak 450 responden.

Hasil: Analisis data yang pertama menurut Permenpan RB nomor 16 tahun 2014 dan yang kedua menggunakan Customer Satisfaction Indeks (CSIndeks). Hasil penelitian ini adalah dengan berdasarkan Permenpan nomor 16 tahun 2014 bahwa seluruh Puskesmas di Kabupaten Hulu Sungai Utara mempunyai nilai IKM dengan kategori baik. Dan dengan menggunakan CSI seluruh puskesmas mempunyai nilai kepuasan dengan kategori cukup puas.

Kesimpulan: Dapat disimpulkan nilai Indeks Kepuasan Masyarakat pada seluruh puskesmas masuk dalam kategori cukup puas. Perbaikan pada fasilitas pendukung seperti toilet yang bersih, ruang tunggu yang nyaman dan bersih, informasi pelayanan, alur pelayanan, peningkatan managemen, dan pemasaran produk harus dilakukan.

Kata Kunci: CSIndeks, Indeks Kepuasan Masyarakat, Permenpan, Puskesmas.

Received: 17 September 2018

Accepted: 10 October 2018

Published: 1 December 2018

\section{PENDAHULUAN}

Pemerintah di dalam menyelenggarakan pelayanan publik masih banyak dijumpai kekurangan sehingga jika dilihat dari segi kualitas masih jauh dari yang diharapkan masyarakat. Hal ini ditunjukkan dengan masih munculnya berbagai keluhan masyarakat melalui media massa. Jika kondisi ini tidak direspon oleh pemerintah maka akan dapat menimbulkan citra yang kurang baik terhadap pemerintah sendiri. Mengingat fungsi utama pemerintah adalah melayani masyarakat 
maka pemerintah perlu terus berupaya meningkatkan kualitas pelayanan publik (Permenpan RB, 2014). Puskesmas merupakan salah satu pelayanan publik yang diselenggarakan oleh pemerintah khususnya di bidang kesehatan.

Puskesmas sebagai suatu unit pelayanan kesehatan yang merupakan ujung tombak dalam bidang pelayanan kesehatan dasar, diharapkan dapat memberikan pelayanan kesehatan yang bermutu dan sesuai dengan kebutuhan pasar atau masyarakat, perlu untuk meningkatkan pelayanan agar mampu bersaing, mampu berkembang, dam mampu bertumbuh.Pelayanan yang diberikan oleh puskesmas harus sesui dengan kebutuhan dan harapan konsumen agar tercipta kepuasan pasien. Ketidakpuasan pasien disebabkan dengan adanya kesenjangan dari pelayanan yang diberikan oleh puskesmas yang tidak sesuai dengan harapan yang dirasakan oleh konsumen, dengan adanya kesenjangan yang diberikan oleh puskesmas tersebut sehingga menimbulkan adanya penilaian yang negatif dari konsumen terhadap pelayanan dan harapan konsumen untuk memakai jasa tersebut akan berkurang (Supriyanto, 2006). Demikian pula Puskesmas di Kabupaten Hulu Sungai Utara yang merupakan Unit Pelaksana Teknis (UPT) Dinas Kesehatan Kabupaten Hulu Sungai Utara bertanggungjawab menyelenggarakan pembangunan kesehatan di suatu wilayah kerja. Puskesmas mempunyai visi yakni tercapainya derajat kesehatan masyarakat, sedangkan misinya adalah menggerakkan pembangunan berwawasan kesehatan di wilayah kerjanya; mendorong kemandirian hidup sehat bagi keluarga dan masyarakat; memelihara dan meningkatkan mutu, pemerataan, dan keterjangkauan pelayanan kesehatan yang diselenggarakan, dan memelihara dan meningkatkan kesehatan perseorangan, keluarga, dan masyarakat beserta lingkungannya.

Untuk mengetahui seberapa besar penilaian terhadap pelayanan yang diberikan oleh Puskesmas Kabupaten Hulu Sungai Utara kepada masyarakat, maka perlu dilakukan suatu pengukuran berupa tingkat kepuasan masyarakat terhadap pelayanan kesehatan yang diterima oleh masyarakat. Puskesmas Kabupaten Hulu Sungai Utara perlu melakukan pengukuran indeks kepuasan masyarakat (IKM) untuk melihat seberapa besar penilaian masyarakat terhadap pelayanan yang diberikan kepada mereka terutama dalam hal pelayanan di Puskesmas setiap tahun. Secara umum, pengukuran IKM yang dilakukan mengacu kepada Peraturan Menteri Pendayagunaan Aparatur Negara dan Reformasi Birokrasi Nomor 16 tahun 2014 tentang "Pedoman Survei Kepuasan Masyarakat Terhadap Penyelenggaraan Pelayanan Publik". Selain berfungsi untuk mengukur dan melihat sebesar tingkat kepuasan masyarakat terhadap pelayanan, kegiatan pengukuran IKM dimaksudkan untuk melihat gambaran dan melakukan pengembangan dan peningkatan kualitas pelayanan yang berkesinambungan sehingga dapat tercipta good corporate governance (Permenpan RB, 2014).

Pengukuran IKM tahun 2015 di Puskesmas Kabupaten Hulu Sungai Utara sangat penting dilakukan sebagai bentuk tindak lanjut sekaligus evaluasi terhadap pelayanan kesehatan yang telah diberikan oleh puskesmas selama ini. Melalui pengukuran IKM ini diharapkan diperoleh nilai IKM yang sesuai sehingga dapat digunakan sebagai landasan kebijakan dalam menetapkan target dan sasaran untuk kegiatan pengembangan dan peningkatan kualitas pelayanan selanjutnya. Penelitian ini bertujuan untuk mengukur Indeks Kepuasan Masyarakat (IKM) terhadap pelayanan kesehatan di seluruh Puskesmas Kabupaten Hulu Sungai Utara tahun 2015.

\section{METODE}

Penelitian ini bersifat obervasional karena tidak memberikan perlakuan pada sampel tetapi hanya melakukan pengamatan. Rancang bangun penelitian ini adalah cross sectional karena data diperoleh dalam waktu yang sama. Metode penelitian yang digunakan adalah survei (survey research method). Lokasi berada di Kabupaten Hulu Sungai Utara dengan waktu penelitian 2 bulan. Kepuasan masyarakat diukur berdasarkan Customer Satisfaction Indeks (CSIndeks). Penelitian ini bersifat observasional. Unit analisis penelitian ini adalah 13 puskesmas di Kabupaten Hulu Sungai Utara. Sampel penelitian adalah masyarakat yang memanfaatkan pelayanan kesehatan di Puskesmas Kabupaten Hulu Sungai Utara dan jumlah sampel ditetapkan sebanyak 450 responden. Instrumen yang digunakan dalam kegiatan survei ini adalah lembar kuesioner yang telah diverifikasi dan divalidasi oleh tim ahli meliputi beberapa pernyataan tentang karakteristik responden, penilaian persepsi responden dan penilaian harapan responden. Tahapan penelitian ini antara lain membuat kuesioner, menghitung sampel, melaksanaan survey, memverifikasi data, mengentri data, dan membuat laporan. Beberapa teknik analisis data yang digunakan adalah secara deskriptif (tabel distribusi frekuensi dan persentase), mengukur kepuasan masyarakat dengan metode Permenpan RB, mengukur kepuasan masyarakat dengan metode Customer Satisfaction Indeks (CSIndeks), dan menampilkan hasil analisis menggunakan spider web analysis.

\section{HASIL DAN PEMBAHASAN}

\section{Karakteristik Responden}

Karakteristik pembeli mempunyai suatu pengaruh yang besar terhadap bagaimana persepsi dan reaksi pembeli terhadap produk yang dikonsumsi (Kotler dan Amstrong, 1995). Karakteristik responden ini dilihat dari karakteristik umur, jenis kelamin, pendidikan terakhir, pekerjaan, jenis pasien, jumlah kunjungan pasien.

Menurut Supranto (2001), pola usia mempengaruhi permintaaan pelayanan kesehatan. Karakteristik responden berdasarkan kelompok umur tertinggi adalah pada kelompok umur $46-55$ tahun yaitu sebesar 22,4\% (101 responden). Sedangkan kategori kelompok umur tertinggi kedua adalah kelompok umur 36 - 45 tahun yaitu sebesar $25,1 \%$ (113 responden) yang artinya sebagian besar responden adalah kelompok umur dewasa, 
hal tersebut merupakan usia produktif sehingga lebih rawan terkena penyakit.

Karakteristik responden berdasarkan jenis kelamin tertinggi adalah jenis kelamin perempuan yaitu sebesar 68,2\% (307 responden) dan jenis kelamin laki-laki adalah sebesar $31,8 \% \quad(143$ responden), hal ini sesuai dengan Dever dalam Ratnawati (2003), bahwa dalam memanfaatkan pelayanan kesehatan ternyata wanita lebih sering menggunakannya.

Karakteristik responden berdasarkan pendidikan terakhir adalah pada pendidikan terakhir SMP yaitu sebesar 29,6\% (133 responden). Sedangkan kategori pendidikan terakhir tertinggi kedua adalah SD yaitu sebesar 26,9\% (121 responden), pendidikan yang berbeda akan mempengaruhi pilihan konsumen terhadap produk maupun merek.

Karakteristik responden berdasarkan pekerjaan adalah pekerjaan lainnya yaitu sebesar $28,2 \%$ (127 responden), dalam pekerjaan lainnya ini $83 \%$ adalah ibu rumah tangga dan $17 \%$ adalah nelayan. Sedangkan kategori pekerjaan tertinggi kedua adalah wiraswasta yaitu sebesar 26,2\% (118 responden). Pekerjaan ini juga mempengaruhi persepsi kepuasan pelayanan kesehatan, dikarenakan semakin berat pekerjaan seseorang maka semakin rentan terhadap penyakit.

Karakteristik responden berdasarkan jenis pasien adalah pasien BPJS Kesehatan yaitu sebesar 50,7\% (228 responden). Sedangkan kategori jenis pasien tertinggi kedua adalah pasien umum yaitu sebesar 43,8\% (197 responden), dan terdapat 5,6\% (25 responden) yang menggunakan asuransi lain, yang dimaksud asuransi lain disini adalah asuransi swasta dimana responden itu bekerja. Hal tersebut dapat diartikan bahwa masyarakat sudah mulai menggunakan BPJS dalam mendapatkan pelayanan kesehatan.

Karakteristik responden berdasarkan kunjungan pasien adalah kunjungan pasien ke 2 kali yaitu sebesar 36,4\% (164 responden). Sedangkan kategori kunjungan pasien tertinggi kedua adalah kunjungan pasien lebih dari 5 kali yaitu sebesar $31,8 \%$ (143 responden).

\section{Analisis Kepuasan Masyarakat berdasarkan PERMENPAN RB Nomor 16 Tahun 2014}

Indeks kepuasan masyarakat akan kualitas pelayanan yang diperoleh di Puskesmas seKabupaten Hulu Sungai Utara didasarkan pada indikator-indikator yang ada di dalam Peraturan Menteri Pendayagunaan Aparatur Negara Nomor 16 Tahun 2014 tentang Pedoman Survei Kepuasan Masyarakat Terhadap Penyelenggaraan Pelayanan Publik, yang berjumlah sembilan indikator. Dalam Permenpan dan RB survei kepuasan masyarakat merupakan salah satu cara yang digunakan oleh penyelenggara pelayanan publik untuk memperoleh data tentang persepsi masyarakat pengguna sehingga dapat digunakan sebagai informasi dalam meningkatkan kualitas dan melakukan perbaikan dalam hal pelayanan. Sasaran dalam kegiatan pengukuran indeks kepuasan masyarakat yakni mendorong partisipasi masyarakat untuk menilai kinerja penyelenggara pelayanan publik, mendorong penyelenggara pelayanan publik untuk lebih meningkatkan kualitasnya, dan mendorong penyelenggara pelayanan publik untuk lebih inovatif dan kreatif dalam memberikan maupun menyelenggarakan pelayanan publik.

Tabel 1. Nilai tertimbang dari sembilan unsur survei kepuasan masyarakat di Kabupaten Hulu Sungai Utara tahun 2015

No Nama Unsur Penilaian

\begin{tabular}{lll}
\hline 1 & Persyaratan Pelayanan & 0,353 \\
\hline 2 & Prosedur Pelayanan & 0,336 \\
\hline 3 & Waktu Pelayanan & 0,341 \\
\hline 4 & Biaya/ Tarif & 0,342 \\
\hline 5 & Produk Spesifikasi Jenis Pelayanan & 0,318 \\
\hline 6 & Kompetensi Pelaksana & 0,336 \\
\hline 7 & Perilaku Pelaksana & 0,329 \\
\hline 8 & Maklumat Pelayanan & 0,309 \\
\hline 9 & Penanganan Pengaduan, Saran Dan Masukan & 0,307 \\
\hline
\end{tabular}

Pada survei kepuasan masyarakat ini, terdapat sembilan unsur penilaian yaitu persyaratan pelayanan, prosedur pelayanan, waktu pelayanan, biaya atau tarif, produk spesifikasi jenis pelayanan, kompetensi pelaksana, perilaku pelaksana, maklumat pelayanan, dan penanganan pengaduan, saran dan masukan. Survei kepuasan masyarakat terhadap pelayanan kesehatan Kabupaten Hulu Sungai Utara dalam lingkup satu kabupaten. Dengan perhitungan nilai rata-rata setiap unsur ini diperoleh dari rerata nilai "kenyataan" dari setiap aspek yang terdapat dalam unsur. Sehingga dalam menghitung rerata tersebut nilai pembaginya tidak sama untuk setiap unsur karena memang setiap unsur mempunyai jumlah aspek penilaian yang tidak sama. Nilai tertimbang setiap unsur ini diperoleh dari nilai rata-rata setiap unsur dikalikan dengan bobot. Bobot sendiri diperoleh dengan pembagian antara 1 dengan jumlah unsur penilaian sehingga diperoleh 0,09 (bobot sama dengan 0,09). Nilai 1 pada perhitungan bobot merupakan nilai standar yang telah ditetapkan.

Berdasarkan Tabel 1, dapat diketahui bahwa nilai tertimbang paling tinggi dari sembilan unsur tersebut adalah persyaratan pelayanan $(0,353)$ sedangkan nilai terendah adalah penanganan 
pengaduan, saran dan masukan $(0,307)$, aspek penialaian yang terendah kedua adalah maklumat pelayanan $(0,309)$ dan aspek penilaian yang terendah ketiga adalah produk spesifikasi jenis pelayanan $(0,318)$. Hal tersebut dapat diartikan bahwa yang harus menjadi perhatian lebih Dinas Kesehatan Kabupaten Hulu Sungai Utara dalam peningkatan pelayanan puskesmas adalah penanganan pengaduan, saran dan masukan dikarenakan mempunyai penilaian yang paling rendah. Keluhan adalah salah satu indikator atau gejala dan tanda adanya ketidakpuasan layanan yang diberikan pada pasien dan jika tidak ditangani dengan serius akan menyebabkan konsumen tidak akan kembali menggunakan produk atau jasa yang diberikan (Supriyanto dan Ernawaty, 2010).

Pada Gambar 1, ditampilkan nilai tertimbang dari sembilan unsur survei kepuasan masyarat dengan menggunakan Spider Web Analysis dengan tujuan untuk mengetahui unsur mana yang tergolong rendah dan yang tergolong tinggi dengan cara membandingkan dengan rata-rata unsur kepuasan masyarakat.

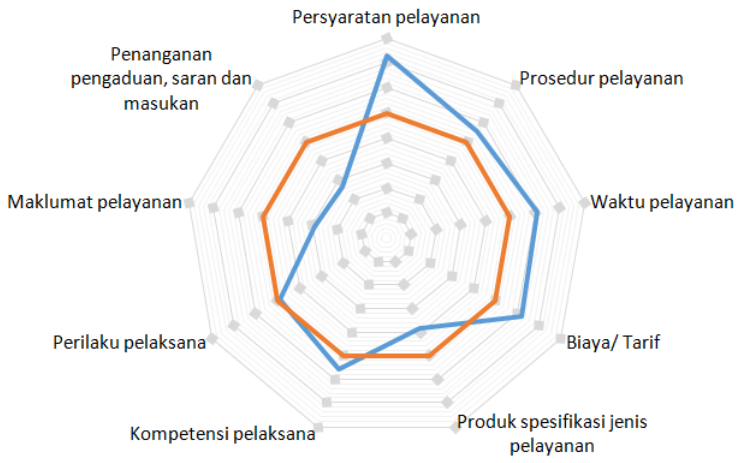

Gambar 1. Spider web analysis nilai tertimbang dari sembilan unsur survei kepuasan masyarakat di Kabupaten Hulu Sungai Utara tahun 2015

Dari Gambar 1, diketahui beberapa unsur yang harus menjadi fokus dalam peningkatan pelayanan puskesmas yaitu dengan membandingkan nilai unsur penialaian (blue line) dengan rata-rata unsur penilaian (orange line), yang di dalam orange line adalah nilai yang masih rendah. Dari beberapa unsur penilaian yang masih rendah dan harus menjadi prioritas dalam peningkatan pelayanan puskesmas diantaranya adalah produk spesifikasi jenis pelayanan, perilaku pelaksana, maklumat pelayanan serta penanganan pengaduan dan masukan. Indikator produk spesifikasi jenis pelayanan dalam kepuasan masyarakat terhadap pelayanan kesehatan puskesmas tergolong rendah yaitu dibawah ratarata nilai aspek pelayanan. Hal tersebut menandakan penilaian pasien yang pernah menjalani atau menerima pelayanan di puskesmas, bahwa dalam hal ini pasien belum mendapatkan kejelasan tentang produk spesifikasi jenis pelayanan yang diterima di puskesmas dan dilayani oleh petugas dengan baik. Indikator maklumat pelayanan dalam kepuasan masyarakat terhadap pelayanan kesehatan pasien di puskesmas Kabupaten Hulu Sungai Utara juga tergoloh rendah. $\mathrm{Hal}$ tersebut menandakan penilaian pasien yang pernah menjalani atau menerima pelayanan di puskesmas, bahwa dalam hal ini pasien belum mendapatkan kejelasan tentang maklumat pelayanan yang diterima di puskesmas. Indikator penanganan pengaduan, saran, dan masukan dalam kepuasan masyarakat terhadap pelayanan kesehatan di Puskesmas Kabupaten Hulu Sungai Utara sangat rendah dibandingkan dengan rata-rata aspek penilaian. Hal tersebut menandakan bahwa dalam hal ini pasien mendapatkan keterbukaan tentang penanganan pengaduan, saran dan masukan pelayanan dari pelaksana pelayanan dengan perilaku yang baik di puskesmas.

Nilai indeks kepuasan masyarakat itu sendiri dapat diperoleh dari jumlah total nilai tertimbang dikalikan dengan 25 . Nilai 25 tersebut merupakan nilai dasar yang telah terstandar. Berdasarkan perhitungan nilai indeks, didapat hasil nilai indeks sebesar 2,971. Nilai indeks kemudian dikonversikan dengan nilai dasar 25. Nilai IKM didapat dengan mengalikan nilai indeks dengan nilai dasar sehingga didapat hasil sebesar 74,26 . Dari perhitungan nilai indeks kepuasan masyarakat setelah di konversi, maka diperoleh hasil bahwa nilai IKM dari pelayanan puskesmas Kabupaten Hulu Sungai Utara tahun 2015 adalah 74,26. Dengan nilai tersebut, mutu pelayanannya termasuk dalam kategori B sehingga dapat disimpulkan bahwa pelayanan pada puskesmas di Kabupaten Hulu Sungai Utara adalah Baik.

Analisis berikutnya adalah menganalisis indeks kepuasan masyarakat per puskesmas. Berdasarkan analisis kepuasan masyarakat per puskesmas. Diketahui bahwa seluruh puskesmas di Kabupaten Hulu Sungai Utara mempunyai nilai IKM dengan kategori baik. Nilai IKM puskesmas paling rendah adalah Puskesmas Banjang yaitu dengan nilai IKM sebesar 71,05. Dari hasil perhitungan indeks kepuasan masyarakat per puskesmas diketahui puskesmas yang menjadi prioritas dalam peningkatan pelayanan puskesmas yaitu puskesmas yang mempunyai nilai kepuasan masyarakat yang rendah. Dikarenakan seluruh puskesmas mempunyai nilai kepuasan masyarakat yang baik, maka nilai IKM tersebut dikategorikan menjadi rendah, sedang dan tinggi dengan tujuan untuk mengetahui puskesmas mana yang menjadi prioritas peningkatan. Cara mengkategorikan nilai IKM tersebut adalah dengan mencari nilai tengahnya (cut off point) yang kemudian aspek kajian tersebut dibobotkan dengan pembobotan masing-masing dan akan dihubungkan dengan nilai tengah (cut off point) dari total penilaian kajian kebutuhan pelayanan rumah sakit.

Nilai tengah (cut off point) dapat diperoleh dengan mengurangkan nilai maksimum dengan nilai minimum lalu dibagi jumlah kategori. Dengan menggunakan tiga skala nilai, rumus perhitungan nilai tengah menghasilkan nilai 1,68. Dengan demikian jenis-jenis kategori yang digunakan adalah kategori satu (rendah) dengan rentang nilai 71,05 72,73 , kategori dua (sedang), dengan rentang nilai 72,74 - 74,40, dan kategori 3 (tinggi), dengan rentang nilai 74,41 - 76,08. Pengkategorian nilai IKM Puskesmas se-Kabupaten Hulu Sungai Utara tersaji pada Gambar 2. 
Berdasarkan Gambar 2 dapat diketahui bahwa puskesmas yang masuk dalam kategori tinggi berjumlah lima puskesmas yaitu Puskesmas Paminggir, Puskesmas Sapala, Puskesmas Danau Panggang, Puskesmas Babirik, dan Puskesmas Pasar Sabtu. Puskesmas yang tergolong dalam kategori sedang berjumlah lima puskesmas yaitu Puskesmas Alabio, Puskesmas Amuntai Selatan, Puskesmas Haur Gading, Puskesmas Guntung, dan Puskesmas Sungai Karias. Sedangkan puskesmas yang masuk kategori rendah berjumlah tiga puskesmas yaitu Puskesmas Sungai Turak, Puskesmas Banjang, dan Puskesmas Sungai Malang. Puskesmas dengan kategori rendah ini yang harus mendapat perhatian lebih dalam peningkatan pelayanan kesehatan. Hal ini tentunya akan menjadi masukan yang baik terhadap pihak terkait dalam mengeluarkan kebijakan akan pelayanan kesehatan dimasyarakat.

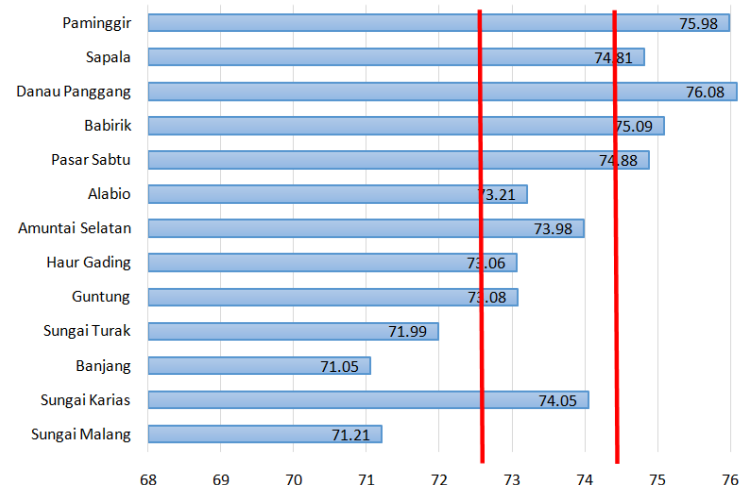

Gambar 2.Grafik pengkategorian nilai IKM puskesmas per puskesmas di Kabupaten Hulu Sungai Utara tahun 2015

\section{Analisis Kepuasan Masyarakat berdasarkan Customer Satisfaction Index (CSIndeks)}

Pada analisis nilai gap (kesenjangan) antara kenyataan dengan harapan pada lima aspek penilaian terhadap pelayanan puskesmas di Kabupaten Hulu Sungai Utara digunakan untuk menentukan seberapa besar kesenjangan yang ada antara kenyataan yang ada pada aspek penilaian dengan harapan dari pasien yang menggunakan aspek - aspek tersebut. Nilai gap ini diperoleh berdasarkan selisih nilai antara kenyataan dan harapan dari setiap aspek penilaian. Semakin besar nilai gap dalam hal ini nilai minus (-) yang diperoleh maka kenyataan yang ada semakin jauh dari ekspektasi pasien. Apabila nilai gap yang diperoleh semakin kecil dalam hal ini nilai minus (-) maka kenyataan yang ada semakin mendekati dari ekspektasi pasien. Sedangkan, semakin besar nilai gap dalam hal ini nilai plus (+) yang diperoleh maka kenyataan yang ada sudah melebihi dari ekspektasi pasien.

Pada analisis nilai gap (kesenjangan) antara kenyataan dengan harapan pada lima aspek penilaian terhadap pelayanan puskesmas di
Kabupaten Hulu Sungai Utara. Untuk analisis nilai customer satisfaction index (CSI) diperoleh berdasarkan perhitungan kenyataan dibagi dengan harapan kemudian hasilnya dikalikan dengan nilai $100 \%$. Hasil dari customer satisfaction index (CSI) adalah persentase yang kemudian dikonversikan menjadi lima kategori yakni tidak puas $(\leq 55,00 \%)$, kurang puas $(55,01 \%-70,00 \%)$, cukup puas $(70,01 \%-85,00 \%)$, puas $(85,01 \%-100,00 \%)$, dan sangat puas $(>100,00 \%)$. Berdasarkan hasil survei yang telah dilakukan terhadap 450 responden yang diambil secara random dari 13 Puskesmas di Kabupaten Hulu Sungai Utara. Hasil skoring nilai gap (kesenjangan) dan nilai CSI dari lima aspek penilaian ditampilkan pada Tabel 2 .

Berdasarkan hasil analisis pada Tabel 2 dapat diperoleh hasil bahwa rata-rata nilai gap dari lima aspek penilaian terhadap pelayanan Puskesmas di Kabupaten Hulu Sungai Utara adalah $-0,88$. Nilai gap yang paling tinggi adalah pada aspek tangible dengan nilai sebesar $-1,00$. Hal ini menunjukkan bahwa ekspektasi pasien yang berkunjung ke puskesmas terhadap gedung puskesmas yang bersih dan tertata rapi, puskesmas memiliki peralatan yang lengkap dan modern, ruang pelayanan di puskesmas bersih dan tenang, puskesmas memiliki ruang tunggu luas dan nyaman, pegawai puskesmas berseragam dan berpenampilan rapi, puskesmas memiliki alur pelayanan yang dapat dilihat dan jelas, memiliki papan informasi yang baik, mempunyai fasilitas toilet yang bersih dengan air yang cukup adalah cukup tinggi. Sedangkan nilai gap paling rendah adalah pada aspek assurance dengan nilai sebesar $-0,82$. Hal ini menunjukkan bahwa kepercayaan masyarakat akan kepastian pelayanan cukup memenuhi harapan pasien. Ini sesuai dengan teori Kotler (2000) yang mengatakan bahwa kepuasan pelanggan adalah tingkat perasaan seseorang setelah membandingkan hasil yang diharapkan dengan apa yang dirasakan.

Terdapat beberapa hal yang dapat dijelaskan dari analisis kesenjangan antar harapan dan kenyataan yaitu semakin panjang kesenjangan yang ditimbulkan antara harapan dan kenyataan pada setiap unsur penilaian, maka hal ini menunjukkan ketidakpuasan responden survei terhadap aspek penilaian tersebut, semakin pendek kesenjangan yang ditimbulkan antara harapan dan kenyataan pada setiap unsur penilaian, maka hal ini menunjukkan kepuasan responden survei terhadap aspek penilaian tersebut, dan dari lima aspek penilaian hanya satu aspek penilaian yaitu tangible yang jarak cukup jauh jika dibandingkan dengan empat aspek penilaian lainnya.

Pada Gambar 3, ditampilkan nilai CSI dengan menggunakan Spider Web Analysis dengan tujuan untuk mengetahui unsur mana yang tergolong rendah dan yang tergolong tinggi yaitu dengan membandingkan antara nilai CSI dengan rata-rata aspek penilaian kepuasan masyarakat.

Tabel 2. Nilai indeks kepuasan masyarakat berdasarkan metode CSIndeks di Kabupaten Hulu Sungai Utara Tahun 2015 


\begin{tabular}{|c|c|c|c|c|c|}
\hline \multirow{2}{*}{ Aspek Penilaian } & \multicolumn{2}{|c|}{ Skoring } & \multirow{2}{*}{ GAP } & \multirow{2}{*}{ CSI } & \multirow{2}{*}{ Keterangan } \\
\hline & Kenyataan & Harapan & & & \\
\hline $\begin{array}{l}\text { TANGIBLE (kebersihan dan kerapian gedung } \\
\text { puskesmas, kelengkapan dan modernitas } \\
\text { peralatan puskesmas, kebersihan dan } \\
\text { ketenangan ruang pelayanan puskesmas, } \\
\text { adanya ruang tunggu puskesmas yang luas dan } \\
\text { nyaman, keseragaman dan kerapian } \\
\text { penampilan petugas puskesmas, kejelasan alur } \\
\text { pelayanan puskesmas, adanya papan informasi } \\
\text { yang baik, adanya fasilitas toilet yang bersih } \\
\text { dengan air yang cukup). }\end{array}$ & 3,00 & 4,00 & $-1,00$ & 74,9 & Cukup Puas \\
\hline $\begin{array}{l}\text { RELIABILITY (kemudahan prosedur penerimaan } \\
\text { pasien, kesesuaian persyaratan pelayanan yang } \\
\text { ditulis dengan jenis pelayanan yang didapat, } \\
\text { ketelitian, kehati-hatian, dan ketepatan waktu } \\
\text { dalam pemberian pelayanan, ketepatan waktu } \\
\text { kedatangan petugas, kesigapan tenaga medis } \\
\text { dan petugas lain dalam membantu pasien, } \\
\text { kelengkapan pemberitahuan mengenai jenis } \\
\text { penyakit, cara perawatan, dan cara minum obat } \\
\text { dari perawat kepada pasien, kepastian informasi } \\
\text { yang diberikan kepada pasien sebelum layanan } \\
\text { diberikan, kejelasan informasi tindakan yang } \\
\text { akan dilakukan tenaga medis). }\end{array}$ & 3,1 & 4,00 & $-0,90$ & 77,5 & Cukup Puas \\
\hline $\begin{array}{l}\text { RESPONSIVENESS (kesediaan tenaga } \\
\text { kesehatan dalam menanggapi keluhan pasien, } \\
\text { kesigapan petugas dalam melayani pasien, } \\
\text { kecekatan petugas dalam melayani pasien, } \\
\text { kecepatan dan ketepatan tenaga kesehatan } \\
\text { dalam melakukan tindakan, kesesuaian tindakan } \\
\text { yang dilakukan oleh tenaga medis terhadap } \\
\text { prosedur yang diterapkan, keramahan } \\
\text { pelayanan yang diberikan kepada pasien.) }\end{array}$ & 3,15 & 4,00 & $-0,85$ & 78,65 & Cukup Puas \\
\hline $\begin{array}{l}\text { ASSURANCE (kemampuan dan pengetahuan } \\
\text { dokter dalam menetapkan diagnosa dan } \\
\text { penyakit, kemampuan dokter dalam menjawab } \\
\text { pertanyaan pasien atau keluarga pasien secara } \\
\text { meyakinkan, kelengkapan obat-obatan dan alat } \\
\text { medis, kecekatan dan penghargaan terhadap } \\
\text { pasien, kewibawaan tenaga kesehatan sehingga } \\
\text { pasien merasa aman, kelengkapan catatan } \\
\text { medis pasien, kesesuaian tarif pelayanan } \\
\text { dengan ketetapan peraturan daerah). }\end{array}$ & 3,18 & 4,00 & $-0,82$ & 79,4 & Cukup Puas \\
\hline $\begin{array}{l}\text { EMPATY (kecukupan waktu pelayanan terhadap } \\
\text { pasien, kesesuaian pelayanan yang diberikan } \\
\text { dengan keinginan dan kebutuhan pasien, } \\
\text { kesungguhan perawat dalam memberikan } \\
\text { perhatian kepada pasien, kesediaan dokter } \\
\text { dalam mendengarkan keluhan yang diderita oleh }\end{array}$ & 3,17 & 4,00 & $-0,83$ & 79,31 & Cukup Puas \\
\hline
\end{tabular}
pasien serta kemampuan dalam memberikan solusi, kesopanan dan keramahan perawat terhadap pasien, kesediaan perawat dalam menerima saran, kritik, dan masukan dari pasien).

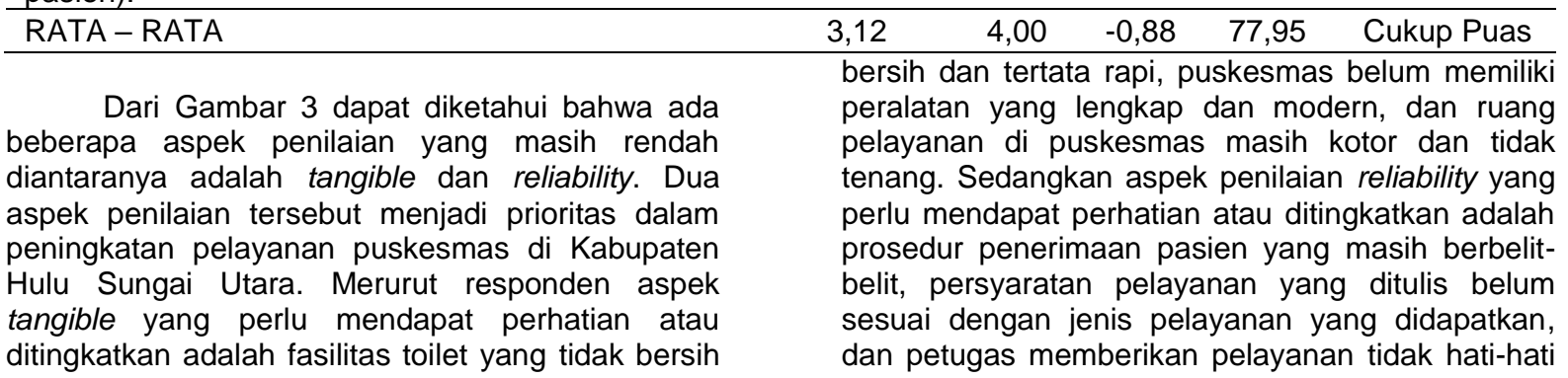
dengan air yang cukup, gedung puskesmas belum 
dan tidak tepat waktu sesuai dengan yang dijanjikan.

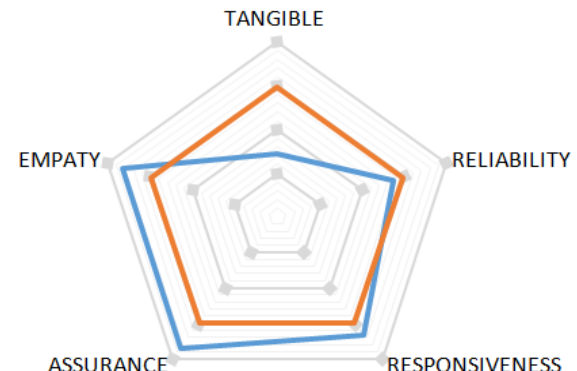

Gambar 3. Spider web analysis lima aspek penilaian puskesmas di Kabupaten Hulu Sungai Utara tahun 2015

Beberapa aspek diatas adalah beberapa aspek yang harus bisa menjadi rujukan ketika pemerintah daearah khususnya Dinas Kesehatan Kabupaten Hulu Sungai Utara dalam membuat kebijakan tentang pelayanan kesehatan di puskesmas. Wijono (1999) menambahkan bahwa kepuasan pasien berkaitan erat dengan pendekatan dan perilaku petugas, perasaan pasien terutama saat pertama kali datang, mutu informasi yang diterima, seperti apa yang dikerjakan, apa yang dapat diharapkan, prosedur perjanjian, waktu tunggu, fasilitas umum yang tersedia, dan outcome terapi dan perawatan yang diterima.
Kepuasan pasien merupakan salah satu indikator kualitas pelayanan kesehatan dan dari aspek ekonomi maka kepuasan pasien akan dapat meningkatkan profit rumah pelayanan kesehatan. Hal ini berhubungan dengan akibat kepuasan pasien terhadap berbagai produk pelayanan kesehatan berpengaruh terhadap keputusan pasien ketika dia membutuhkan suatu pelayanan medik lebih lanjut. Kepuasan bahkan berpengaruh pula terhadap kemungkinan orang tersebut mengajak orang lain untuk menggunakan fasilitas pelayanan kesehatan.

Setelah mengetahui tingkat kepuasan masyarakat akan pelayanan puskesmas di Kabupaten Hulu Sungai Utara secara global, berikutnya menganalisis tingkat kepuasan masyarakat per puskesmas dengan metode GAP analisis dan CSI. Berdasarkan hasil analisis kepuasan per puskesmas berdasarkan analisis GAP dan CSIndeks diketahui bahwa seluruh Puskesmas di Kabupaten Hulu Sungai Utara mempunyai nilai kepuasan dengan kategori cukup puas. Nilai kepuasan puskesmas paling tinggi adalah Puskesmas $L$ yaitu dengan nilai CSIndeks sebesar 84,29, sedangkan nilai kepuasan puskesmas paling rendah adalah Puskesmas Kabupaten Hulu Sungai Utara yaitu dengan nilai CSIndeks sebesar 75,00.

Dikarenakan seluruh puskesmas mempunyai nilai kepuasan masyarakat dengan kategori cukup puas, maka nilai IKM tersebut dikategorikan menjadi rendah, sedang dan tinggi dengan tujuan untuk mengetahui puskesmas mana yang menjadi prioritas peningkatan.

Tabel 3. Nilai IKM dengan metode GAP dan CSIndeks per puskesmas di Kabupaten Hulu Sungai Utara tahun 2015

\begin{tabular}{cccccccc}
\hline \multirow{2}{*}{ No } & \multirow{2}{*}{ Puskesmas } & \multicolumn{2}{c}{ Skoring } & \multirow{2}{*}{ GAP } & \multirow{2}{*}{ CSI } & \multirow{2}{*}{ Keterangan } & \multirow{2}{*}{ Kategori } \\
\cline { 3 - 4 } & & Kenyataan & Harapan & & & & \\
\hline 1 & Sungai Malang & 3,01 & 4,00 & $-0,99$ & 75,29 & Cukup Puas & Rendah \\
\hline 2 & Sungai Karias & 3,06 & 4,00 & $-0,94$ & 76,47 & Cukup Puas & Rendah \\
\hline 3 & Banjang & 3,21 & 4,00 & $-0,79$ & 80,29 & Cukup Puas & Sedang \\
\hline 4 & Sungai Turak & 3,06 & 4,00 & $-0,94$ & 76,59 & Cukup Puas & Rendah \\
\hline 5 & Guntung & 3,03 & 4,00 & $-0,97$ & 75,82 & Cukup Puas & Rendah \\
\hline 6 & Haur Gading & 3,04 & 4,00 & $-0,96$ & 76,06 & Cukup Puas & Rendah \\
\hline 7 & Amuntai Selatan & 3,08 & 4,00 & $-0,92$ & 76,97 & Cukup Puas & Rendah \\
\hline 8 & Alabio & 3,03 & 4,00 & $-0,97$ & 75,65 & Cukup Puas & Rendah \\
\hline 9 & Pasar Sabtu & 3,11 & 4,00 & $-0,89$ & 77,85 & Cukup Puas & Rendah \\
\hline 10 & Babirik & 3,16 & 4,00 & $-0,84$ & 79,00 & Cukup Puas & Sedang \\
\hline 11 & Danau Panggang & 3,00 & 4,00 & $-1,00$ & 75,00 & Cukup Puas & Rendah \\
\hline 12 & Sapala & 3,37 & 4,00 & $-0,63$ & 84,29 & Cukup Puas & Tinggi \\
\hline 13 & Paminggir & 3,05 & 4,00 & $-0,95$ & 76,18 & Cukup Puas & Rendah \\
\hline
\end{tabular}


Cara mengkategorikan nilai IKM tersebut adalah dengan mencari nilai tengah nya (cut off point) setelah itu aspek kajian tersebut dibobotkan dengan pembobotan masing-masing dan akan dihubungkan dengan nilai tengah (cut off point) dari total penilaian kajian kebutuhan pelayanan puskesmas. Nilai tengah (cut off point) dapat diperoleh dengan mengurangkan nilai maksimum dengan nilai minimum lalu dibagi jumlah kategori. Dengan menggunakan tiga skala nilai, rumus perhitungan nilai tengah menghasilkan nilai 3,10 . Dengan demikian jenis-jenis kategori yang digunakan adalah kategori satu (rendah) dengan rentang nilai 75,00 - 78,10, kategori dua (sedang), dengan rentang nilai $78,11-81,19$, dan kategori 3 (tinggi), dengan rentang nilai 81,19 - 84,29. Pengkategorian nilai IKM Puskesmas se-Kabupaten Hulu Sungai Utara dengan metode GAP dan CSIndeks tersaji pada Tabel 3.

Berdasarkan Tabel 3 dapat diketahui bahwa puskesmas yang masuk dalam kategori tinggi berjumlah 1 puskesmas yaitu Puskesmas Sapala. Puskesmas yang tergolong dalam kategori sedang berjumah 2 puskesmas yaitu Puskesmas Banjang dan Puskesmas Babirik. Sedangkan puskesmas yang masuk kategori rendah berjumlah 10 puskesmas yaitu Puskesmas Sungai Malang, Puskesmas Sungai Karias, Puskesmas Sungai Turak, Puskesmas Guntung, Puskesmas Haur Gading, Puskesmas Amuntai Selatan, Puskesmas Alabio, Puskesmas Pasar Sabtu, Puskesmas Danau Panggang, dan Puskesmas Paminggir. Banyaknya puskesmas yang masuk dalam kategori rendah yang menjadi prioritas perbaikan pelayanan Puskesmas diKabupaten Hulu Sungai Utara.

\section{SIMPULAN}

Berdasar penjabaran pada hasil dan pembahasan, didapat kesimpulan bahwa nilai IKM dari pelayanan puskesmas Kabupaten Hulu Sungai Utara tahun 2015 adalah 74,26 , mutu pelayanannya termasuk dalam kategori baik. Seluruh Puskesmas di Kabupaten Hulu Sungai Utara mempunyai nilai IKM dengan kategori baik. Setelah dikategorikan dengan tiga kategori diketahui puskesmas yang masuk kategori rendah berjumlah tiga puskesmas yaitu Puskesmas Sungai Malang, Puskesmas Banjang, dan Puskesmas Sungai Turak. Berdasarkan perhitungan Nilai Indeks Kepuasan Masyarakat (IKM) menurut Customer Satisfaction Indeks (CSI Indeks) menunjukkan bahwa rata-rata nilai gap dari lima aspek penilaian terhadap pelayanan Puskesmas di Kabupaten Hulu Sungai Utara adalah -0,88. Seluruh Puskesmas di
Kabupaten Hulu Sungai Utara mempunyai nilai kepuasan dengan kategori cukup puas. Setelah dikategorikan dengan tiga kategori (tinggi, sedang, dan rendah) diketahui bahwa 10 puskesmas masuk dalam kategori rendah.

\section{DAFTAR PUSTAKA}

Arikunto, S. (2010) Prosedur Penelitian: Suatu Pendekatan Praktik. Jakarta: Rineka Cipta.

Fornell, C. (1992) 'A National Customer Satisfaction Barometer: The Swedish Experience', Journal of Marketing, 56(1), pp. 6-21. Available at: https://www.jstor.org/stable/pdf/1252129.pdf.

Kementerian Pendayagunaan Aparatur Negara dan Reformasi Birokrasi Republik Indonesia (2014) Peraturan Menteri Pendayagunaan Aparatur Negara dan Reformasi Birokrasi Nomor 16 Tahun 2014 Tentang Pedoman Survei Kepuasan Masyarakat Terhadap Penyelenggaraan Pelayanan Publik. Indonesia.

Kotler, P. (1994) Manajemen Pemasaran: Analisis, Perencanaan dan Pengendalian. 5th edn. Edited by C. Hasibuan. Jakarta: Erlangga.

Kotler, P. (1997) Manajemen Pemasaran: Analisis, Perencanaan, Implementasi dan Kontrol. 2nd edn. Jakarta: Prenhalindo.

Kotler, P. (2000) Manajemen Pemasaran. 1st \& 2nd edn. Jakarta: Prenhalindo.

Menteri Pendayagunaan Aparatur Negara (2004) Keputusan Menteri Pendayagunaan Aparatur Negara Nomor: Kep/25/M.Pan/2/2004 Tentang Pedoman Umum Penyusunan Indeks Kepuasan Masyarakat Unit Pelayanan Instansi Pemerintah. Indonesia.

Supriyanto, S. (2010) Pemasaran Industri Jasa Kesehatan. Edited by O. HS. Yogyakarta: Andi.

Supranto, J. (2001) Pengukuran Tingkat Kepuasan Pelanggan untuk Menaikkan Pangsa Pasar. Jakarta: Rineka Cipta.

Türkyılmaz, A. and Özkan, C. (2007) 'Development of a customer satisfaction index model', Industrial Management \& Data Systems, 107(5), pp. 672-687. doi: 10.1108/02635570710750426.

Valarie A. Zeithaml, L. L. B. and A. P. (1996) 'The Behavioral Consequences of Service Quality', Journal of Marketing, 60(2), pp. 3146.

Wijono, D. (2000) Manajemen Mutu Pelayanan Kesehatan. 1st \& 2nd edn. Surabaya: Airlangga University Press. 